\title{
The Revealed Comparative Advantage Index of Brazilian Natural Honey
}

\author{
Maristela F. de Paula ${ }^{1}$, Humberto Angelo ${ }^{2}$, Alexandre N. de Almeida ${ }^{2}$, Eder P. Miguel ${ }^{2}$, Pedro G. A. Vasconcelos ${ }^{2}$, \\ Ari Schwans ${ }^{1}$, Marcio A. Facini ${ }^{1}$, Ademir J. F. Ribas ${ }^{1} \&$ Raquel S. Pompermeyer ${ }^{3}$ \\ ${ }^{1}$ Department of Administration, State University of West Centre, Guarapuava, PR, Brazil \\ ${ }^{2}$ Department of Forestry Engeneering, University of Brasilia, Campus Darcy Ribeiro, Brasilia, DF, Brazil \\ ${ }^{3}$ Federal University of Valleys of Jequitinhonha and Mucuri, Teófoli Otoni, MG, Brazil \\ Correspondence: Pedro G. A. Vasconcelos, Department of Forestry Engeneering, University of Brasilia, Campus \\ Darcy Ribeiro, CEP: 70919-970, DF, Brazil. Tel: 55-(61)-3107-5637. E-mail: pedroguilherme.av@gmail.com
}

Received: June 26, 2017

doi:10.5539/jas.v9n11p76
Accepted: August 30, $2017 \quad$ Online Published: October 15, 2017

URL: https://doi.org/10.5539/jas.v9n11p76

\begin{abstract}
Natural honey is considered a valuable forestry product not only for biodiversity but also to its conservation functions. Besides, it is an important exported commodity. In this study, the performance of Brazilian natural honey exported products were evaluated with specific focus on determination of their competitiveness in the international market. This article aimed to calculate the Revealed Comparative Advantage Index (RCA) of Brazilian natural honey, from 2000 to 2015. The sources consulted are SEBRAE, IBGE, Brazilian Ministry of Development, Industry and Foreign Trade and the United Nations Commodity Trade Statistics Database (UN COMTRADE). The methodological procedure used was Balassa's Revealed Comparative Advantage Index in order to estimate the competitiveness measure. The results demonstrated that Brazil was competitive in natural honey exported products during the period from 2002 to 2015 . Considering the outcomes, based on the indexes it is possible to affirm that Brazilian natural honey is competitive and the country displays enough positive characteristics and productive capacity to amplify its participation in new international commercial markets.
\end{abstract}

Keywords: competitiveness, exports, honey, international market

\section{Introduction}

The presence of Brazilian honey has grown in international markets since 2000. Brazil has become one of the largest exporters of honey in a short time due to its social, economic, and environmental characteristics, which enabled the development of beekeeping (Pasin et al., 2012). In addition, this growth can be attributable to temporary embargoes on two important countries in the export market: China and Argentina.

These restrictions were made by the European Community suspending the Chinese honey imports resulted from the elevated indexes of veterinary drugs in their product and simultaneously, the United States suspended honey imports from Argentina, alleging price distortions, which caused unfair competition with US producers. This was an antidumping initiative (ABEMEL, 2015).

The world market for honey stands out because of the variations in its quality and production. Further diversity is found in the range of products originating from apiculture such as: wax, propolis, pollen, royal jelly, and bee venom (Zandonadi \& Silva, 2006).

In this context, the international natural honey market is considered an alternative to the development of apiarian activity in Brazil, because it has low environmental impact and provides incomes to rural producers.

Given this potential, it is relevant to analyze the competitiveness of Brazilian honey exports, from 2000 to 2015. It is also pertinent to demonstrate the potential of the natural honey market, which includes: identifying Brazil's role in the worldwide market and verifying the evolution of the Comparative Advantages of natural honey.

Several researchers have developed studies using Revealed Comparative Advantages. The following works can be highlighted as examples of this: Ilha et al. (2006), Rubin et al. (2008), Pais et al. (2008), Fernandes and Santos (2011), Siqueira and Pinha (2012), Santetti and Azevedo (2013), Dorneles et al. (2013), and Almeida et al. 
(2013). This research aims to measure the comparative advantages of the Brazilian natural honey regarding major worldwide exporters.

\section{Method}

Bela Balassa proposed the Revealed Comparative Advantages (RCA) theory in 1965. This is based on the Comparative Advantages model first formulated by David Ricardo. Lafay further developed RCA theory in 1987. The Revealed Comparative Advantages Index indicates that if the exports of a certain product have an index of over one, the country or block will possess revealed comparative advantage over the production of this product when compared to other countries. Conversely, if the exports have an index lower than one, the country or block possesses revealed comparative disadvantage (Fernandes \& Santos, 2011).

The index reveals the level of a country's exports for one product in relation to its total exports and compares products between different countries. The competitiveness of the country is a result of the level of expertise that country has in both the international and domestic levels of production (Freitas \& Massuquetti, 2013).

The Revealed Comparative Advantage index is given by the following equation:

$$
\operatorname{IVCR}_{\mathrm{j}}=\left(\mathrm{X}_{\mathrm{ij}} / \mathrm{X}_{\mathrm{i}}\right) /\left(\mathrm{X}_{\mathrm{wj}} / \mathrm{X}_{\mathrm{w}}\right)
$$

Where,

$X_{i j}=$ Value of the Brazilian exports for natural honey; $X_{i}=$ Total value of the Brazilian exports; $X_{w j}=$ Total value of the worldwide exports for natural honey; $X_{w}=$ Total value of the worldwide exports; $i=$ Brazilian exports; $w$ $=$ Worldwide exports; $\mathrm{j}=$ Natural honey.

Where,

$\mathrm{IVCR}_{\mathrm{j}}>1 \rightarrow$ the country has comparative advantage for natural honey exports; IVCR $\mathrm{j}<1 \rightarrow$ the country has comparative disadvantage for natural honey exports.

\subsection{Data Sources}

The data used to calculate these indexes in the Brazilian context were collected using the Foreign Trade Analysis System (FTAS), from the Secretary of Foreign Trade (SFT). The institution owns data regarding Free on Board (FOB) Brazilian exports in dollars as well as export data from the United Nations Commodity Trade Statistics Database (UN COMTRADE).

\section{Results and Discussion}

\subsection{The International Market for Natural Honey}

In order to understand the international market for natural honey, we use deterministic data regarding natural honey exports. This data is analyzed in order to focus its presentation and discussion as follows: using descriptive statistics, analysis of variance and averages tests.

Worldwide honey exports, both in quantity and value, display a crescent trend from 2000 to 2015 (Figure 1). This is the case even when considering the variations attributed to the embargoes, the increase in number of hives and production per colony follow an increase in consumption during the last few years. Zandonadi and Silva (2006) emphasize that the expansion in consumption is related to a general increase in income and standards of living in the world as a whole, as well as due to the greater interest in natural and healthy products. During the analyzed period, the worldwide exports of honey reached 7.1 million tons with an estimated value of US\$ 21.5 billion. 


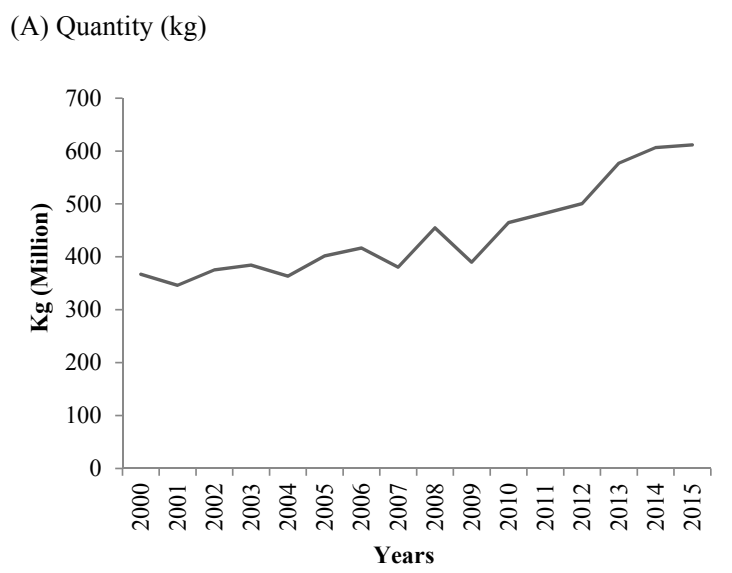

(B) Value (US\$)

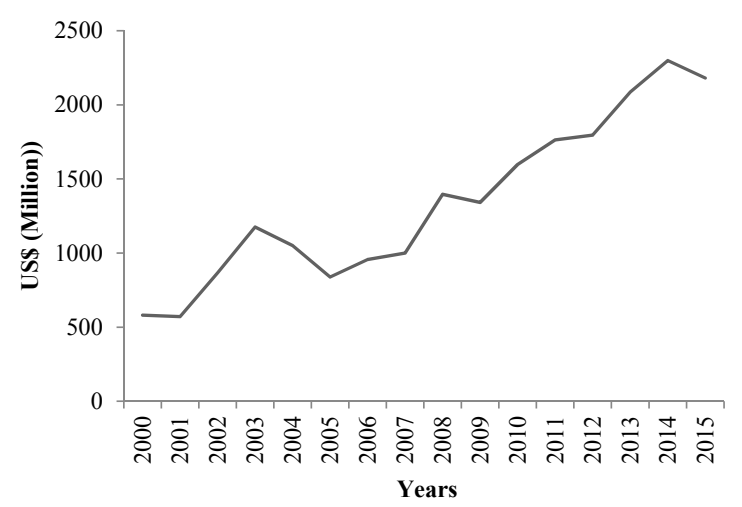

Figure 1. Evolution of the quantity (a) and value (b) of natural honey exports from 2000 to 2015

Source: UN COMTRADE (2016)—Data elaborated by the authors.

Worldwide exports of natural honey were reduced (Figure 1) between 2003 and 2004, due to the restrictions imposed on China (quality issues) and Argentina (antidumping), these are important countries in regarding world honey exports. However, in 2005, when restrictions came to an end the exports grew. In 2008, exports stagnated once again, due to the global crisis and crop failure in China, Argentina, and Vietnam, caused by climate changes. A further reason for stagnation was the antidumping measures against China, imposed by the United States (Paula, 2008).

In 2010, the expansion was constant in world exports, with only negative variations in exports values in the years of 2012 and 2015. Despite the variations, average prices remained most of time above US\$2.50 (Table 1). Throughout the historical series being evaluated, there were variations in quantity and the value (Figure 1; Table 1) of natural honey exports. The law of supply and demand caused most of these variations.

Table 1. Worldwide exports of natural honey in quantity $(\mathrm{kg})$, value (US\$), and average price (US\$) from 2000 to 2015

\begin{tabular}{llllll}
\hline Year & Quantity $(\mathrm{kg})$ & Variation (\%) & Real Value (US\$) & Variation (\%) & Average Price (US\$/kg) \\
\hline 2000 & 367158186 & 0 & 581438000 & 0 & 1.58 \\
2001 & 346326465 & -6 & 571409000 & 4 & 1.65 \\
2002 & 375470891 & 8 & 866274000 & 40 & 2.31 \\
2003 & 384495383 & 2 & 1176271000 & 33 & 3.06 \\
2004 & 363560981 & -5 & 1050865000 & -6 & 2.89 \\
2005 & 401658333 & 10 & 838075000 & -28 & 2.09 \\
2006 & 416705349 & 4 & 956539000 & 10 & 2.30 \\
2007 & 380437304 & -9 & 999879000 & 14 & 2.63 \\
2008 & 454931674 & 20 & 1396306000 & 17 & 3.07 \\
2009 & 389898568 & -14 & 1341330000 & 12 & 3.44 \\
2010 & 464751019 & 19 & 1597282000 & 0 & 3.64 \\
2011 & 482609417 & 4 & 1764202000 & 6 & 3.59 \\
2012 & 500471828 & 4 & 1796533000 & -2 & 3.62 \\
2013 & 576950585 & 15 & 2087196000 & 1 & 3.79 \\
2014 & 606658904 & 5 & 2299779000 & 5 & 3.57 \\
2015 & 611472814 & 1 & 2180449000 & -6 & 3.02 \\
\hline TOTAL & 7123557701 & & 21503831000 & & \\
Average & 445222356 & & 1343989000 & & \\
\hline
\end{tabular}

Source: UN COMTRADE (2016)—Data elaborated by the authors. 
By analyzing Figure 2 and Table 1, it is possible to verify that the average price increased during the initial years of the decade and decreased when China and Argentina returned to the international market, after the restrictions imposed on them were ended. The average price decreased, mostly between 2004 and 2005, which can be attributed to the large supply of honey provided by these countries, once the product remained stocked during the embargo period. After that, the price began to present a crescent trend and the variations on the quantity had some negative values but most of them were positive variations showing the expansion of the market.

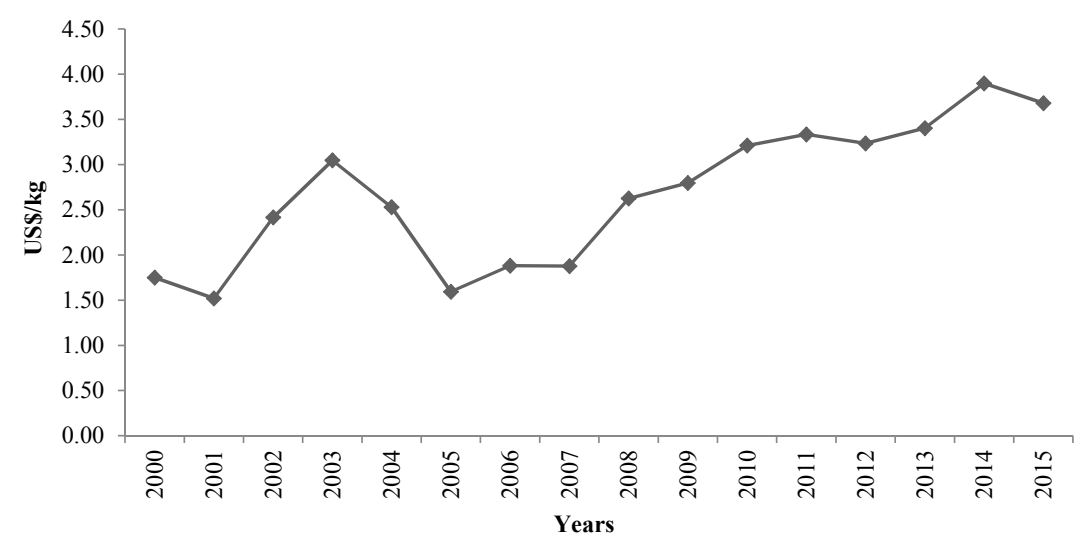

Figure 2. Evolution of the average price of natural honey in worldwide exports, from 2000 to 2015

Source: UN COMTRADE (2016)—Data elaborated by the authors.

The international market exported 402.333 million tons on average, which corresponds to US\$ 1.039 .163 billion. Argentina and China were the main exporters in the period being studied (UN COMTRADE, 2016). From 2008, the international market stabilized, because the main exporters presented the same growth on average and prices sustained the worldwide average, except for China, whose prices were always below average.

\subsection{Main Exporters of Natural Honey}

During the period under analysis, the worldwide exports of natural honey reached 4.8 billion tons, of which the major exporters are: China, Argentina, Mexico, Germany, Canada, Hungary, Brazil, and Spain (Figure 3).

China represented $21 \%$ of total exports around the world (Figure 3 ), being the main exporter of natural honey during the period evaluated, followed by Argentina, with $16 \%$. These countries remained the market leaders in quantity and value of exports for the entire period.

The other significant exporters (Canada, Spain, Brazil, Hungary, Germany and Mexico) contributed roughly with 3 to $7 \%$ of total exports (Figure 3), presenting a constant trends throughout the analysis period. These countries gained market during the embargoes and some countries exported more than they produced by importing honey at lower prices and then adding it to their production. They would then export these imports under their own label (Perez et al., 2004; Zandonadi \& Silva, 2006). 
(A) Quantity exported of natural honey

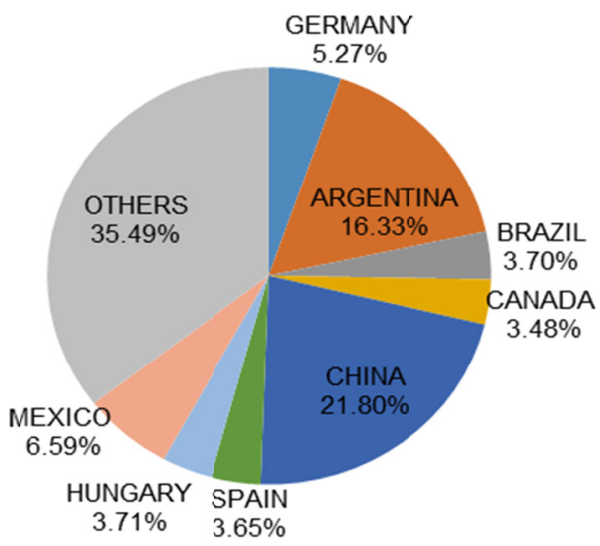

(B) Value exported of natural honey

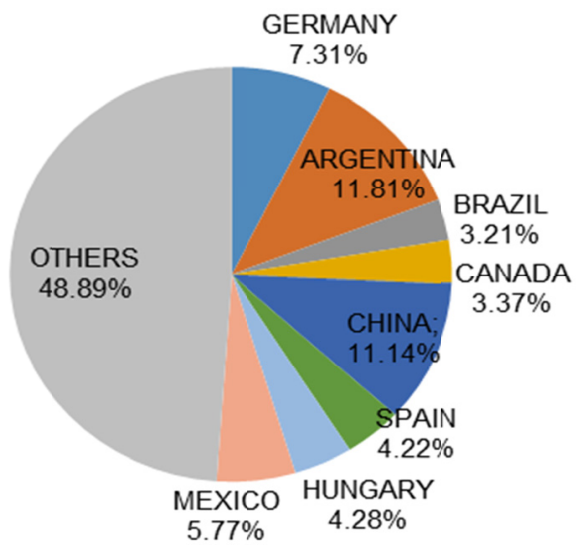

Figure 3. Export percentage of the main exporters of natural honey, from 2000 to 2015

Source: UN COMTRADE (2016)—Data elaborated by the authors.

Other countries represent $35 \%$ of world exports, including producers with lower market share, such as: Ethiopia, Tanzania, Angola, and Kenya, in Africa; as well as India, Ukraine, and Iran, in Asia. These countries are great producers and consumers of honey, since this product is part of the population dietary habits (Perez et al., 2004).

China and Argentina exported practically the same value (US\$) of honey, although the production of the South-American country was approximately $25 \%$ smaller. This is related to the Argentine tradition of exporting agricultural products and to the elevated honey consumption in Asian countries.

Germany was another country highlighted for the impressive values of their exports, being considered the fourth highest exporter and the second largest importer of honey in the world during the period being studied. This country practices re-exportation: importing honey from other countries, adding value to the product and then exporting the honey for a higher price. It is considered the main distributer of honey in Europe.

Paula (2008) emphasizes that few countries dominate the world market; however, there are not impediments for other producers to participate. Böhlke and Palmeira (2006) said that Brazilian apiculture activity became a tool to promote inclusion, employment, and alternative income increasing exports and market attractiveness.

The descriptive statistics of the quantity and export value of natural honey of the main exporters, between 2000 and 2015, is presented in Table 2.

Mexico and Germany obtained quantities over 20 million tons of natural honey. Germany, however, obtained the higher value for exports in the period being studied (Table 2). According to Zandonadi and Silva (2006), it is due to the practice of re-exportation.

Table 2. Statistical analysis of the quantity $(\mathrm{kg})$ and exportation value (US\$) of natural honey in the main export markets, from 2000 to 2015

\begin{tabular}{lllllllll}
\hline & China & Argentina & Mexico & Germany & Canada & Hungary & Brazil & Spain \\
\hline Quantity (kg) of natural honey (million) & & & & & & \\
Minimum & 64.35 & 45.60 & 19.03 & 20.09 & 9.46 & 12.42 & 0.27 & 7.71 \\
Average & 97.05 & 72.72 & 29.32 & 23.45 & 15.48 & 16.51 & 16.46 & 16.25 \\
Maximum & 144.76 & 107.63 & 42.16 & 27.60 & 35.62 & 24.16 & 25.99 & 30.15 \\
Standard Deviation & 40.90 & 31.26 & 11.64 & 3.78 & 14.86 & 6.13 & 13.28 & 11.54 \\
Value (US\$) of the natural honey exported (million) & & & & & & \\
Minimum & 102.70 & 95.70 & 37.57 & 47.85 & 28.46 & 22.59 & 0.47 & 19.99 \\
Average & 166.43 & 176.34 & 86.19 & 109.16 & 50.31 & 64.00 & 47.88 & 63.09 \\
Maximum & 288.67 & 235.45 & 155.99 & 151.30 & 76.25 & 95.77 & 98.69 & 120.57 \\
Standard Deviation & 97.47 & 70.69 & 60.14 & 52.60 & 23.98 & 36.90 & 49.13 & 50.80 \\
\hline
\end{tabular}

Source: UN COMTRADE (2016)—Data elaborated by the authors. 
Canada, Hungary, Brazil, and Spain exported an average quantity of over 15 million tons of honey between 2000 and 2015. These countries represent the producers that gained more space at the market during the timeline of this study.

China obtained a higher average for quantity of natural honey exported, followed by Argentina that obtained the higher maximum values for quantity and gross value during the exportation period evaluated.

Brazil, considered an intermediate producer, obtained the lowest values for production and exports during the period being evaluated (Table 2). This fact can be attributed to the development stage of the country and the small share that Brazil had in this market in the beginning of 2000s, as observed by Perez et al. (2004), Zandonadi and Silva (2006).

\subsection{Main Importers of Natural Honey}

Since honey production of the developed countries does not match internal demand, the countries with large consumer markets are the main importers. From 2000 to 2015, the main importers of natural honey were the United States, Germany, Japan, the United Kingdom, Italy, and Belgium (Figure 4).

Towards the end of the analysis period, the demand and consumption of honey presented a crescent trend, due to the imports increasing in some traditional markets and the additional demand of new countries, such as Lebanon, Saudi Arabia, Oman, and Syria (UN COMTRADE, 2016).

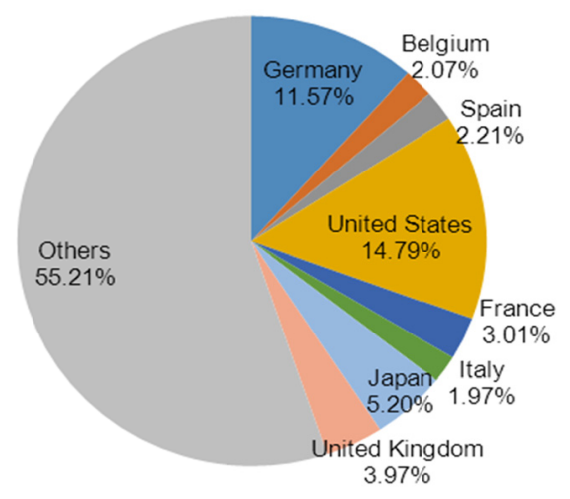

Figure 4. Main importers of natural honey, in the period from 2000 to 2015

Source: UN COMTRADE (2016)—Data elaborated by the authors (2016).

The numbers presented in Table 3 reveal the fact that the honey importers are, usually, wealthy and challenging countries when it comes to quality and supply commitment, since they need the product to maintain stable demand.

When the average price per kilogram of the product is evaluated, it is possible to observe that the importer countries have an extensive range going from US\$ 1.93 to US\$ 3.26 .

Table 3 describes the values of the main importers of honey, in terms of quantity, gross value (US\$) and average price (US\$) paid per kilogram of honey in the analyzed period.

Table 3. Total imports of the main consumer countries of natural honey from 2000 to 2015

\begin{tabular}{llll}
\hline Countries & Quantity $(\mathrm{kg})$ & Gross value (US\$) & Average Price (US\$) \\
\hline USA & 1202933956 & 2698656685.63 & 2.24 \\
Germany & 1089880423 & 2785421510.73 & 2.56 \\
Japan & 496376360 & 955990477.41 & 1.93 \\
UK & 341306413 & 1015298776.61 & 2.97 \\
France & 248920700 & 812349329.02 & 3.26 \\
Spain & 176695943 & 386464581.36 & 2.19 \\
Italy & 166021922 & 489364673.64 & 2.95 \\
Belgium & 149352910 & 387484982.40 & 2.59 \\
\hline
\end{tabular}

Source: UN COMTRADE (2016)—Data elaborated by the authors (2016). 
During the period evaluated, the main importers of natural honey were the United States and Germany, with 15\% and $12 \%$, respectively. Japan and the United Kingdom are also highlighted, with $5 \%$ and $4 \%$ of imports respectively (Figure 4 , Table 3). Together, these countries sum $36 \%$ of world imports.

Germany and the United States are the main importers of natural honey (Table 3). They were arguably responsible for the acceleration and subsequent decline in the quantity and value of imports, because of the embargoes imposed on exporters, such as China, Argentina, and Brazil.

The quantity imported and the imports value did not follow the same trend during the period analyzed, from 2000 to 2015. The descriptive statistical analysis of the import quantity and value of imports of natural honey worldwide, between 2000 and 2015, is presented in Table 4 .

Table 4. Statistical analysis describing the quantity $(\mathrm{kg})$ and import value (US\$) of natural honey for the main importers, from 2000 to 2015

\begin{tabular}{lllllllll}
\hline & USA & Germany & Japan & UK & France & Spain & Italy & Belgium \\
\hline $\begin{array}{l}\text { Quantity imported (kg) of natural honey (million) } \\
\text { Minimum }\end{array}$ & 65.75 & 78.55 & 36.22 & 22.03 & 14.79 & 11.40 & 10.78 & 6.65 \\
Average & 114.90 & 89.87 & 40.40 & 30.84 & 23.35 & 17.18 & 15.28 & 16.02 \\
Maximum & 175.41 & 100.32 & 47.03 & 41.57 & 35.86 & 30.65 & 23.55 & 32.15 \\
Standard Deviation & 55.12 & 10.89 & 5.54 & 9.81 & 10.71 & 10.36 & 6.65 & 13.19 \\
\hline Import value (US\$) & of natural honey imported (million) & & & & & \\
Minimum & 102.18 & 142.01 & 53.24 & 34.10 & 29.56 & 17.79 & 20.23 & 19.58 \\
Average & 307.85 & 259.60 & 90.75 & 96.90 & 83.90 & 39.80 & 50.97 & 43.41 \\
Maximum & 605.32 & 337.64 & 123.98 & 133.55 & 153.80 & 72.75 & 91.29 & 89.85 \\
Standard Deviation & 255.72 & 99.79 & 35.43 & 51.41 & 62.60 & 28.01 & 35.85 & 36.79 \\
\hline
\end{tabular}

Source: UN COMTRADE (2016)—Data elaborated by the authors.

The United States obtained the largest average for quantity of natural honey imports between 2001 and 2015, followed by Germany (Table 4) which despite having a smaller population than the United States and other countries of the list, the country occupies the second position because besides the internal demand, Germany practices the re-exportation of honey.

To a better understanding of this statistics on Table 4, it is necessary to account the respective population of the countries and that is why the USA has the leading values in quantity and imports values for the reason that it is a developed country with the largest population among the countries on the list of the Table 4.

The countries with the minor deviation on quantity were Japan and Italy meaning that their demand did not change much from the average in compare to the other countries, but analyzing the deviation on the import values the country with the minor values were Japan, Italy and Belgium. Therefore, the Belgium imports of honey grew in quantity but the import values variation were close with the Japan and Italy values meaning that this countries were able to import honey with less variations on the prices.

\subsection{Brazilian Market for Natural Honey Exports}

By the end of the 1990s, Brazil was underdeveloped in the world market for natural honey; however, in the beginning of the 2000s, Brazilian exports became an alternative to the honey produced by Argentina and China (Zandonadi \& Silva, 2006).

During the initial years of the decade in question, the main world exporters of natural honey faced embargoes imposed by the European Union and United States. In this period, the international honey market suffered with supply issues.

Brazil, which directed its production towards the internal market, began to increase its participation on the international market since it presented favorable circumstances for new producer countries because of the embargoes faced by the main exporters.

This fact is corroborated by ABEMEL (2015), who affirmed that Brazil tripled its production, due to the European and North-American demand, that resulted in shortages and subsequent price rises in the international market. According to Paula (2008), this fact encouraged Brazilian production to be redirected towards the 
international market. In this context, Brazilian exports increased, going from an approximately 260 tons of exports, in 2000, to more than 22 million tons exported in 2015 (Table 5).

Table 5. Evolution of the Brazilian natural honey exports from 2000 to 2015

\begin{tabular}{llll}
\hline Year & Quantity $(\mathrm{kg})$ & Gross value $($ US\$) & Average Price $(\mathrm{US} \$ \mathbf{k g})$ \\
\hline 2000 & 269103 & 342171.00 & 1.27 \\
2001 & 2489214 & 2826839.00 & 1.14 \\
2002 & 12643362 & 23172952.00 & 1.83 \\
2003 & 19273750 & 45569637.00 & 2.36 \\
2004 & 21037120 & 42386237.00 & 2.01 \\
2005 & 14447958 & 18972455.00 & 1.31 \\
2006 & 14601908 & 23372924.00 & 1.60 \\
2007 & 12907267 & 21194121.00 & 1.64 \\
2008 & 18271297 & 43571114.00 & 2.38 \\
2009 & 25987195 & 65791416.00 & 2.53 \\
2010 & 18629061 & 55021353.00 & 2.95 \\
2011 & 22398577 & 70868550.00 & 3.16 \\
2012 & 16707413 & 52347767.00 & 3.13 \\
2013 & 16180566 & 54123900.00 & 3.89 \\
2014 & 25317263 & 98576057.00 & 3.68 \\
2015 & 22205915 & 81719968.00 & \\
\hline Total & 263366969 & 699857461.00 & \\
\hline
\end{tabular}

Source: UN COMTRADE (2016) —Data elaborated by the authors (2016).

The country elevated its exports significantly between 2001 and 2004, presenting a $745 \%$ growth, far above the $0.15 \%$ average registered worldwide.

The Brazilian development in the sector was interrupted in the middle of 2004, due the end of the embargoes being imposed on China and Argentina. China returned to the European market with competitive prices, which resulted in an elevated stock. China was able to sell their product in a way that was too difficult for the competition to meet. The mounting demand for increased honey quality is a characteristic of this period; the price decreased in order to adapt to the market (Table 5).

In 2006, the Brazilian natural honey exports go through an impairment since the European Union, the main honey importer, suspended Brazilian honey imports. The decision stated by the European Federation of Food, Agriculture and Tourism Trade Unions was based on persistent failures in the waste monitoring system.

It is important to highlight that in 2003, a technical committee from Europe came to Brazil aiming to analyze the traceability and health of several agribusiness chains, including natural honey. The European technicians recommended the construction of laboratories for controlling and monitoring waste, which was not done by the Brazilian government, culminating in the establishment of an embargo on the Brazilian product. These restrictions were considered merely bureaucratic by ABEMEL (2015).

During the period of this study, the North-American market became the main destination for the Brazilian exports, accounting for approximately $70 \%$ of natural honey exports. Despite European Union restrictions, Brazilian exports grew by $12 \%$, from 2005 to 2009 .

Initially the Europe embargo towards Brazil was an obstacle for the Brazilian aspirations in the world market for honey; however, it has had positive consequences. One of these consequences was to draw the attention of entrepreneurs into the beekeeping sector allowing them to fill the need to strengthen the sectors organizations. As consequence of the Europe restriction, Brazil directed its exports to the United States reaching a market little explored up to that point.

Brazil returned to the European market in 2008 for two reasons: the Brazilian government constructed the laboratories to control and monitor honey waste, and the pressure applied by European countries, caused by the lack of product in their territories (Sebrae, 2006). 
This highlights the importance of proper management of the production process with respects to the marketing of products. Proper use of management and marketing technologies are necessary conditions in order to meet the requirements of the international natural honey market (Khan et al., 2009).

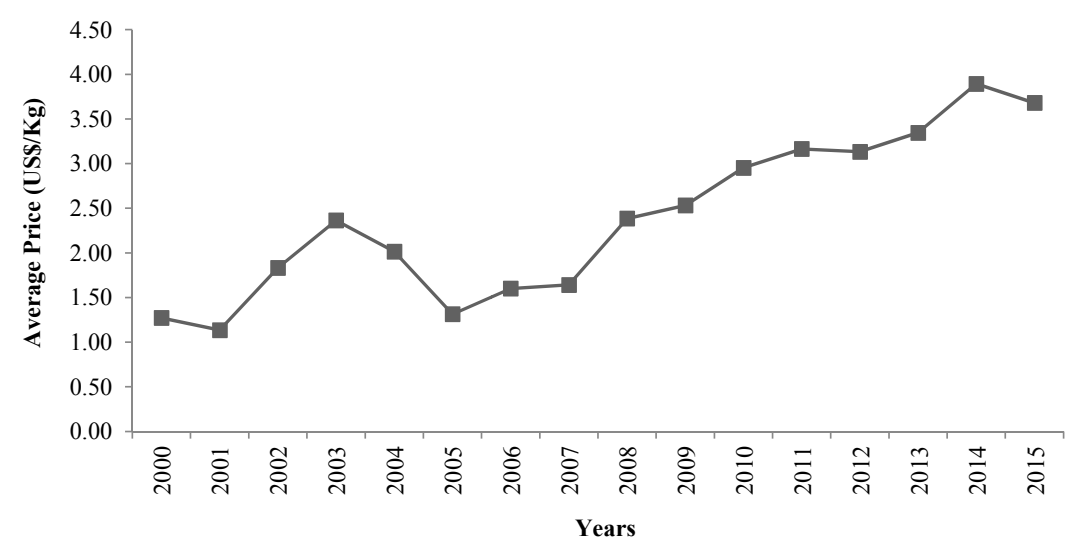

Figure 5. Evolution of the average price of natural honey in Brazil exports, from 2000 to 2015

Source: UN COMTRADE (2016)—Data elaborated by the authors.

It was verified that Brazil presented low export volumes in 2000, and the average price went from US\$ 1.27 to US\$ $3.68 / \mathrm{kg}$, during the period being studied. The increase of the average value between 2001 and 2004 was constant. The highest average price occurred in 2014 , US $\$ 3.89 / \mathrm{kg}$, and the lowest in 2001 , US\$ $1.14 / \mathrm{kg}$. Between the years of 2005 and 2007 is possible to visualize the effect of the period of impediment on Brazilian natural honey by the European Union (Table 5, Figure 5).

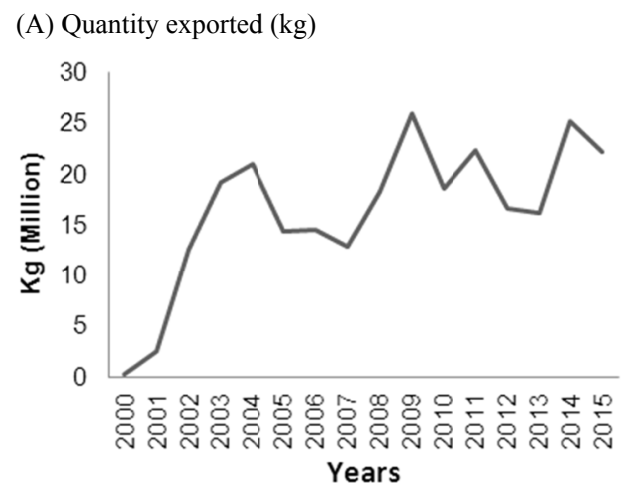

(B) Value Exported (US\$)

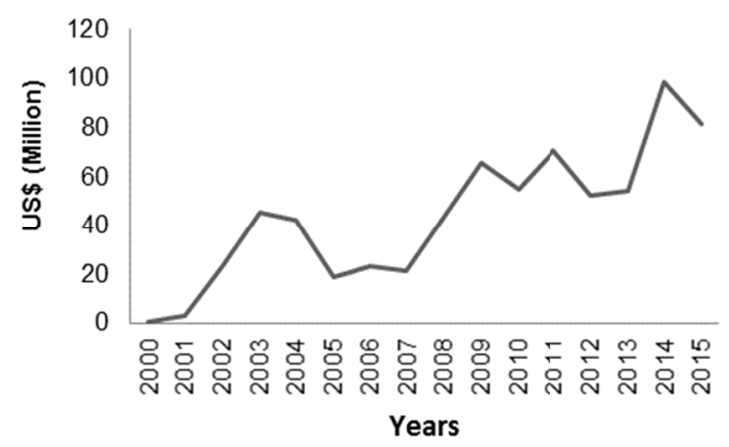

Figure 6. Evolution of the quantity exported (A) and value exported (B) of Brazilian natural honey from 2000 to 2015

Source: UN COMTRADE (2016)—Data elaborated by the authors (2016).

After the Argentine and Chinese honeys return to the international market there was an increase in the quantity of honey offered in the market, and because of that the quantity and value of the exports of Brazilian natural honey decreased (Figure 6), but the Brazilian exports did not come back to the initial levels of the 2000s. This indicates that Brazil gained a significant section of the market (Paula, 2008).

The volume of natural honey that Brazil exported (Table 5) was significant, reaching, in 2015, 22.2 million tons. However, during this period, there were variations (Figure 6), which demonstrated that the international market for natural honey is dynamic and competitive. Therefore, it is necessary for Brazil to be attentive to the evolution of this market, beyond developing quality products at competitive prices. This is in accordance with industry 
competition standards as well as the capacity for new technology and human capital developments (Zandonadi \& Silva, 2006; Paula, 2008).

Zandonadi and Silva (2006) say that the honey price, at a world level, is affected by several factors, such as: the supply and demand conditions in the importing countries, the quality and the type of honey available for exportation, and whether substitutes are available and the existence of taxes and commercial barriers. Sebrae (2006) added that the national beekeeping market is affected by imbalances between supply and demand in the international market. These factors have determined the variations in prices of Brazilian honey.

Paula (2008) affirmed that notwithstanding the growth of the market in Brazil in recent years, the international market, which is the main goal of most producers, is highly competitive, especially because the major exporters (China and Argentina) capacity to influence prices. Considering that, the success or failure of the Brazilian export of honey is conditional whether it is capable of increasing its competitiveness.

Brazil is among the main leaders in the international natural honey market, with a crescent trend in its exports (Coronel et al., 2011). However, variations are evident over the last period (Figure 6). This is due to several factors, such as: the production conditions and demand from importer and re-exporter countries; the quality and type of honey; as well as the existence of taxes and commercial barriers that influence Brazilian exports (Zandonadi \& Silva, 2006).

\subsection{Revealed Comparative Advantages of Brazilian Honey}

The Revealed Comparative Advantages Index allows for the identification of the importance of a certain product in the Brazilian export agenda, considering the world context. Table 6 indicates the values found in the Revealed Comparative Advantages Index (RCA) for the period analyzed.

Table 6. Revealed Comparative Advantages Index of Brazilian honey, from 2000 to 2015

\begin{tabular}{|c|c|c|c|c|c|c|c|c|c|c|c|c|c|c|c|c|}
\hline Anos & 2000 & 2001 & 2002 & 2003 & 2004 & 2005 & 2006 & 2007 & 2008 & 2009 & 2010 & 2011 & 2012 & 2013 & 2014 & 2015 \\
\hline IVCR & 0.094 & 0.74 & 4.42 & 6.28 & 6.34 & 3.24 & 3.36 & 1.88 & 2.64 & 5.67 & 2.8 & 2.98 & 2.29 & 2.06 & 3.62 & 3.25 \\
\hline
\end{tabular}

Source: UN COMTRADE (2016) —-Data elaborated by the authors (2016).

The RCA was analyzed in accordance with the classification provided by Pais et al. (2008), in which, (a) IVCR $>$ 1 means the country has revealed comparative advantage for natural honey exports; and (b) $\mathrm{IVCR}_{\mathrm{j}}<1$ means the country has revealed comparative disadvantage for natural honey exports.

According to the results, the Brazilian natural honey went from a comparative disadvantage position in 2000 to a comparative advantage in 2002, and from 2002 to 2015, all indexes indicated a revealed comparative advantage with the highest value of the index being 6.34 in the year of 2004 .

The Table 6 exhibit the indexes results from 2000 to 2015. From 2002 to 2004, with the introduction of the restrictions on the main exporters of natural honey, the Brazilian competiveness increased considerably. The end of these embargoes in 2004 caused a reduction in the revealed comparative advantage index in 2005 and 2006. After that, the embargo imposed on Brazilian honey by the European Union in 2007 reduced its market advantage when compared to previous years. In 2008, when the restrictions ended, the index increased again, reaching the third highest index value in 2009 (5.67), because of the production reduction in the United States and Argentina, caused by climatic factors. From 2010 to 2015, the indexes indicated values in accordance with the average standards of the world market and these numbers show greater competiveness of the Brazilian natural honey.

Further evidence of the potential of Brazilian honey in the international market was the quick response to increase production caused by the increase of external demands, caused by the crisis faced by two major providers. Additionally, the quality of Brazilian honey surpasses Argentina's, since Brazilian exports are all natural honey whereas the Argentine's is blended (ABEMEL, 2015). These restrictive measures significantly alter the external market of several countries and must be considered as a constant threat to all new market players who have not yet adapted their production to the requirements of importers.

This study on the performance of Brazilian natural honey exports made important points about evolution, participation and competitiveness of this product in the international market made it possible to know the position and competitiveness of Brazil in the global market for natural honey exports and generated several information showing the importance of exports to leverage the beekeeping sector. 
The indexes presented on the Table 6 also expresses the fact that Brazil present favorable characteristics as diverse flora and favorable climate evidencing Brazil's potential to be a top producer offering to the market a differentiated product for its quality and flavor. It shows that the Brazilian natural honey is one of the best in the market and is preferred by the main consumer markets worldwide, due to the lack of waste and for its quality standards. These factors have contributed to the growth of apiculture in Brazil, and, consequently, to its part in the international market.

The main aspect to increase the competitiveness of Brazilian honey is the organization of the beekeeping sector, through cooperatives and associations, in order to access lines of credit and financing. Other factors, such as technical assistance, training of beekeepers and certifying the quality of Brazilian honey, provided by the Ministry of Agriculture, Livestock and Supply and stated by the Federal Inspection Service and other institutions will contribute to increase the competitiveness of Brazilian honey and guaranteeing Brazil's position in the international market (Sebrae, 2006).

Finally, for the improvement of the competiveness of the Brazilian honey there is the need to develop quality products and competitive prices, according to industry standard for competition, as well as the capacity for innovation in technology and human capital formation. In addition, it is necessary to create a strategically and important commercial association with Europe consumers.

\section{Conclusion}

It is concluded that Brazilian natural honey presents comparative revealed advantage and is competitive in the international market.

The Revealed Comparative Advantage index confirms that the Brazilian product has become significant in the international market, and Brazil is among the world's leading providers of honey.

In this work, Brazil's importance was stated with respect to natural honey exports. Once the country has a recognized product quality it has the potential to become one of the main exporters of honey worldwide.

Therefore, it is necessary to adopt policies in order to create a differential to the national product, aiming the raising of the competitiveness by the valorization of the quality and increase of the price of the exported product.

\section{References}

ABEMEL (Associação Brasileira dos Exportadores de Mel). (2015). Retrieved from http://www.beebrazil.com/ abemel.aspx

Almeida, A. N., Silva, J. C. G. L., \& Angelo, H. (2013). Competitividade do Brasil e Canadá no mercado de madeira serrada de coníferas. Ciência Florestal, 3, 439-448. https://doi.org/10.5902/1980509810555

Böhlke, P. B., \& Palmeira, E. M. (2006). Inserção competitiva do pequeno produtor de mel no mercado internacional. Revista Acadêmica de Economia, 72, 1-7. Retrieved from http://www.eumed.net/cursecon/ ecolat $/ \mathrm{br} / 06 / \mathrm{pbb} . \mathrm{htm}$

Coronel, D. A., Sousa, E. P., \& Amorim, A. L. (2011). Desempenho exportador do mel natural nos estados brasileiros. Pesquisa \& Debate, 22, 343-360. Retrieved from https://revistas.pucsp.br/index.php/rpe/article/ view/11749

Dorneles, T. M., Dalazoana, F. M. L., \& Schlindwein, M. M. (2013). Análise do índice de vantagem comparativa revelada para o complexo da soja sul-mato-grossense. Revista de Economia Agricola, 1, 5-15.

Fernandes, R. A. S., \& Santos, C. M. (2011). Competitividade das exportações sucroalcooleiras do Estado de São Paulo. Revista de Política Agrícola, 4, 50-57. Retrieved from https://seer.sede.embrapa.br/index.php/ $\mathrm{RPA} /$ article/view/24

Freitas, G. S., \& Massuquetti, A. (2013). A Competitividade e o grau de concentração das exportações do complexo soja do Brasil, da Argentina e dos Estados Unidos da América No Período 1995/2010. Revista Eletrônica em Gestão, Educação e Tecnologia Ambiental, 16, 3113-3133. https://doi.org/10.5902/2236117 010602

Ilha, A. D. A. S., \& Coronel, D. A. (2006). Vantagens comparativas reveladas e orientação regional da soja brasileira frente à União Européia e ao foro de cooperação econômica na Ásia e no Pacífico (1992-2004). Revista de Economia e Agronegócio, 4, 43-62.

Khan, A. S., Matos, V. D., \& Lima, P. V. P. S. (2009). Desempenho da apicultura no estado do Ceará: Competitividade, nível tecnológico e fatores condicionantes. Revista de Economia e Sociologia Rural, 3, 651-675. https://doi.org/10.1590/S0103-20032009000300006 
Pais, P. S., Gomes, M. F. M., \& Coronel, D. A. (2008). Análise da competitividade das exportações brasileiras de minério de ferro, de 2000 a 2008. Revista de Administração Mackenzie, 13, 121-145. https://doi.org/10.1590/S1678-69712012000400006

Pasin, L. E. V., Tereso, M. J. A., \& Barreto, L. M. R. C. (2012). Análise da produção e comercialização de mel natural no Brasil no período de 1999 a 2010. Agroalimentaria, 34, 29-42. Retrieved from http://www.saber.ula.ve/handle/123456789/35377

Paula, J. (2008). Mel do Brasil: As exportações brasileiras de mel no período 2000/2006 e o papel do Sebrae (p. 99). SEBRAE, Brasília, Brasil.

Perez, L. H., Resende, J. V., \& Freitas, B. B. (2004). Exportações brasileiras de mel natural no período 2001-2003. Informações Econômicas, 34, 28-37.

Rubin, L. S., Ilha, A. S., \& Waquil, P. D. (2008). O comércio potencial brasileiro de carne bovina no contexto de integração regional. Revista Economia e Sociologia Rural, 46, 1067-1091. https://doi.org/10.1590/ S0103-20032008000400007

Santetti, M., \& Azevedo, A. F. Z. (2013). Evolução das exportações da região sul e do Brasil nos anos 2000: Competitividade e perfil tecnológico. Revista Economia e Desenvolvimento, 25, 46-63. https://doi.org/ 10.5902/red.v1i25.7430

SEBRAE (Serviço Brasileiro de Apoio às Micro e Pequenas Empresas). (2006). Desafios da Apicultura Brasileira (p. 63). SEBRAE, Brasília, Brasil.

Siqueira, K. B., \& Pinha, L. C. (2012). Vantagens comparativas reveladas e o contexto do Brasil no comércio internacional de lácteos. Informações Econômica, 3, 40-49.

UN COMTRADE (United Nations Commodity Trade Statistics Database). (2016). Retrieved from http://comtrade.un.org/db/dqBasicQuery.aspx

Zandonadi, D. A., \& Silva, O. M. (2006). Competitividade das exportações brasileiras de mel. Revista Econômica do Nordeste, 37, 37-53.

\section{Copyrights}

Copyright for this article is retained by the author(s), with first publication rights granted to the journal.

This is an open-access article distributed under the terms and conditions of the Creative Commons Attribution license (http://creativecommons.org/licenses/by/4.0/). 